\title{
REINTERPRETASI KONSEP MAHRAM DALAM PERJALANAN PEREMPUAN PESPEKTIF HERMENEUTIKA FAZLUR RAHMAN
}

\begin{abstract}
Holilur Rohman
Fakultas Syariah dan Hukum UIN Sunan Ampel Surabaya. Email: elrahman10@gmail.com

Abstract: Discuss the issue of women is no end. Every angle of women invites a discussion that must be done in depth, including the issue of hadith which describes the necessity of a mahrom for women when they want to travel. On the one side the necessity of mahram has a positive impact for the security and protection of women, but on the other side invites problems because the dynamics of women's lives today that require doing activities outside the home without having to be accompanied by mahrom. Really a dilemma for women. On the one side want to live his life according to the command of religion by following the hadith of the Prophet, but on the other side, when following hadith textualy will make her busy in activity outside the home. Therefore, this paper will discuss more deeply the problem of women's journey by reinterpretation mahram concept of Fazlurrahman hermeneutic perspective, in order to find the best solution for Muslim women in particular, for Muslims in general.
\end{abstract}

Keywords: women's journey, Mahram, Fazlurrahman hermeneutic.

Abstrak: Membahas persoalan perempuan seakan tidak ada habisnya. Setiap sudut perempuan mengundang diskusi yang harus dilakukan secara mendalam, termasuk persoalan hadis-hadis Nabi yang menjelaskan tentang keharusan adanya mahrom bagi perempuan ketika mau mengadakan perjalanan. Di satu sisi keharusan tersebut berdampak positif demi keamanan dan perlindungan perempuan, tapi di sisi lain mengundang problem karena dinamika kehidupan perempuan zaman sekarang yang mengharuskan melakukan aktifitas di luar rumah tanpa harus didampingi mahrom. Sungguh dilematis bagi perempuan. Di satu sisi ingin menjalani hidupnya sesuai perintah agama dengan cara mengikuti hadis Nabi, tapi di sisi lain, ketika mengikuti bunyi tekstual hadis akan menjadikannya semakit repot dalam beraktiftas di luar rumah. Oleh karena itu, tulisan ini akan membahas lebih mendalam persoalan perjalanan perempuan dengan cara reinterpretasi dan reaktualisasi konsep mahram perspektif hermeneutika Fazlurrahman, agar ditemukan solusi terbaik bagi perempuan muslimah pada khususnya, bagi umat Islam pada umumnya. 
Kata kunci: Perjalanan perempuan, Mahram, Hermeneutika Fazlurrahman

\section{Pendahuluan}

Fakta sejarah mengatakan bahwa perempuan dalam lintasan sejarah sebelum Islam datang menjadi kelas kedua dalam struktur masyarakat. Pada zaman yang lalu, baik di Yunani, Romawi, penganut Hindu dan beberapa negara lain, mereka menjadikan perempuan hanya sebagai objek, bukan subyek yang mempunyai hak-hak hukum sebagaimana laki-laki.

Sebelum Islam datang, budaya Arab sering mengubur hiduphidup bayi perempuan yang baru lahir, menjadikan perempuan sebagai barang warisan, membolehkan poligami tanpa batas, kekerasan dalam rumah tangga dilegalkan tanpa ada sangsi. Lalu Islam datang memiliki visi agung sebagai agama rahmatan lil 'alamin. Islam menshari'atkan ajaran-ajaran yang menghapuskan diskriminasi terhadap perempuan.

Islam mengangkat derajat perempuan setinggi-tingginya. Perempuan pun berhak mendapat warisan, dilarang pula melakukan kekerasan dalam rumah tangga tanpa alasan yang dibenarkan, poligami mulai dibatasi hanya sampai 4 orang, dan aturan-aturan lain yang sangat memihak terhadap perempuan. AlQur'an dan dan as-Sunnah lah yang menjadi pioner dan pahlawan sejati untuk merealisasikan semuanya.

Akan tetapi sistem patriarki-misoginis tidak bisa dihilangkan begitu saja. Dengan menyandarkan pada beberapa hadis nabi, sebagian ulama' tetap menomerduakan wanita dalam struktur masyarakat. Lalu muncullah pelarangan terhadap perempuan untuk melakukan perjalanan tanpa didampingi mahramnya. Inilah yang sampai saat ini menjadi problem dalam diskursus hukum Islam.

Di sisi lain terkait dengan perjalanan seorang wanita, ada sebuah penelitian menyebutkan 80 persen masalah TKI di luar negeri ternyata berawal dari kampung halaman mereka. Aneka carut marut pembuatan dokumen, calo TKI dan sebagainya menjadi cikal bakal masalah TKI di luar negeri. Untuk itu, tulisan ini bermaksud melihat bagaimana redaksi hadis Nabi tentang pelarangan perjalanan perempuan tanpa mahram, bagaimana 
pendapat para ulama' menyikapi perjalanan perempuan, serta bagaimana reinterpretasi hadis Nabi tentang mahram dan aplikasinya terhadap perjalanan perempuan dengan mahram, khususnya yang terkait dengan para TKI dalam pembacaan Hermeneutika Fazlur Rahman.

\section{Sekilas Sejarah Perempuan}

1. Penganut Hindu

Disebutkan dalam hukum-hukum Hindu, wabah kematian, neraka, racun, ular dan api lebih baik daripada wanita. Disebutkan dalam hukum Manu yang merupakan sebagian dari ajaran Hindu, bahwa pada masa kecil wanita tunduk kepada ayahnya, pada masa muda tunduk kepada suaminya, pada masa jandanya tunduk kepada anak-anaknya. Dan ketika dia tidak mempunyai anak dan sanak saudara, ia tunduk kepada kerabat suaminya dan tidak boleh urus dirinya sendiri. ${ }^{1}$

2. Zaman Yahudi

Pada zaman Yahudi, sebahagian orang menjadikan anak perempuan setaraf pelayan, dan ayahnya berhak menjualnya. Wanita boleh menerima waris, kecuali bila ayahnya tidak mempunyai keturunan anak-anak lelaki. ${ }^{2}$

Para penganut Yahudi menganggap bahwa perempuan adalah sumber laknat karena dialah yang menyebabkan sumber laknat karena dialah yang menyebabkan Adam diusir dari surga.

3. Bangsa Romawi

Dinyatakan dalam hukum Romawi, perempuan dianggap hamba lelaki dan sebagai barang dagangan murah yang dapat dipergunakan sebagaimana dikehendaki. Ia menguasai wanita sesuai keinginannya sehingga hidupnya menjadi milik ayahnya, kemudian suaminya, kemudian anakanaknya. Pemilikan mereka terhadapnya sama seperti memiliki hewan dan benda mati. Laki-laki melihat kepada perempuan

${ }^{1}$ Mustafa al-Siba'i, al-Mar'ah bain al-Figh wa al-Qanun, (Kairo:Dar al-Salam, 1998), hlm. 15.

${ }^{2}$ Ibid. 
Holilur Rohman: Reinterpretesi Konsep Mahram...

sebagai pembangkit syahwat dan perempuan itu syaitan dan kotor, dan ia tidak memiliki kekuasaan atas kebetinaannya. ${ }^{3}$

4. Kode Hammurabi ${ }^{4}$

Dalam kode Hammurabi terdapat ketentuan-ketentuan khusus yang sifatnya membatasi kehidupan perempuan dan memposisikan perempuan sebagai "jenis kelamin kedua" (the second sex) di setiap level masyarakat. Dalam kode Hammurabi sebagaimana dikutip oleh Nasaruddin Umar disebutkan:

"Bilamana seorang perempuan gagal menjadi istri yang baik, sering berkeluyuran, melalaikan tugas-tugasnya di rumah, dan melecebkan suaminya, maka perempuan tersebut harus dilemparkan ke dalam air. ${ }^{5}$

5. Zaman Jahiliyah Arab

Posisi perempuan pada zaman jahiliah Arab sebelum hadirnya Islam sangatlah rendah. Kedudukan perempuan jauh berbeda dengan laki-laki dan tidak mendapatkan hak-hak yang diperoleh laki-laki. Pada zaman itu perempuan tidak mendapatkan warisan, bahkan menjadi harta waris untuk anaknya ketika suaminya meninggal, tidak mendapatkan hak apapun dari suaminya, tidak ada batasan poligami, tidak ada hak memilih calon suaminya, dan lain sebagainya. ${ }^{6}$

Di zaman itu pula perempuan mendapat penghormatan yang amat sedikit sekali. Pada waktu-waktu tertentu di kalangan sebagian kecil bangsa Arab. Ramai wanita dianiayai. Beberapa contoh terburuk perlakuan bahkan paling kejam ialah menguburkan bayi hidup-hidup. Bayi perempuan di kalangan Arab zama jahiliyah amat menyedihkan dan sangat

${ }^{3}$ Ibid, 12.

${ }^{4}$ Hammurabi adalah tokoh beribawa yang hidup sekitar tahun 1800 S.M. Dia membangun suatu kerajaan dan mengembangkan suatu masyarakat multi-kota yang disebut dengan masyarakat Hammurabi. Kode Hammurabi dikenal sebagai hukum Mesopotamia dan dianggap sebagai salah satu naskah hokum pertama yang lebih lengkap dalam sejarah umat manusia. Lihat Nasaruddin Umar, Argumen Kesetaraan Gender Perspektif al-Qur'an, (Jakarta: Paramadina, 2001), hlm. 95.

${ }^{5}$ Ibid, 97.

${ }^{6}$ Mustafa al-Siba'i, al-Mar'ah bain al-Fiqh wa al-Qanun, hlm. 17. 
hina. Banyak kasus penguburan hidup-hidup bayi yang tidak berdosa.

Dalam al-Qur'an Surah an-Nahl ayat 58 dan 59 disebutkan:

Dan apabila seseorang dari mereka diberi kabar dengan (kelabiran) anak perempuan, bitamlah (merah padamlab) mukanya, dan dia sangat marah. Ia menyembunyikan dirinya dari orang banyak, disebabkan buruknya berita yang disampaikan kepadanya. Apakah Dia akan memeliharanya dengan menanggung kehinaan ataukah akan menguburkannya ke dalam tanah (bidup-bidup) ?. Ketabuilah, alangkah buruknya apa yang mereka tetapkan itu.

Setelah kedatangan Islam, martabat kaum wanita diangkat dan dimuliakan. Tiada lagi diskriminasi terhadap kaum wanita dan mereka juga mempunyai hak-hak tertentu di dalam kehidupan. Begitulah adilnya Islam terhadap kaum wanita dan telah membebaskan mereka dari diskriminasi yang telah sekian lama membelenggu diri mereka.

\section{Hadits-Hadits Yang Melarang Wanita Bersafar Tanpa Mahram}

Banyak hadits yang melarang wanita bersafar/bepergian tanpa mahram, di antaranya:

1. Dari 'Abdullah bin 'Umar, bahwasanya Nabi SAW bersabda:

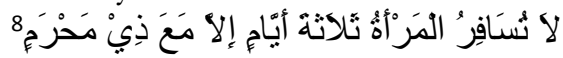

"Tidak boleh seorang wanita mengadakan perjalanan selama tiga hari, kecuali bersama mahram."

2. Dalam riwayat Muslim dari hadits Abu Said al-Khudri, Rasulullah SAW bersabda:

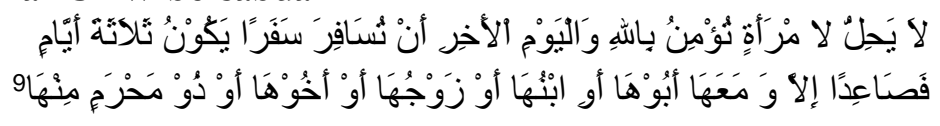

${ }^{7}$ Ibid, 18.

8 Abi Abdillah Muhammad Bin Isma'il Al-Bukhari, al-Jami' al-Sabih, , juz 4, maktabah shamilah, 331 .

${ }_{9}^{9}$ Muslim bin al-Hajjaj Abu al-hasin al-Qushairi al-Naisaburi, Sabih Muslim, juz 2, maktabah shamilah, 977. 
Holilur Rohman: Reinterpretesi Konsep Mahram...

"Tidak halal bagi seorang wanita yang beriman kepada Allah dan hari akbir untuk mengadakan perjalanan yang memakan waktu selama tiga hari lebih, melainkan ia harus didampingi oleb ayabnya, anaknya, suaminya, saudaranya, atau mabramnya."

3. Hadits 'Abdullah Ibnu 'Abbas, ia berkata: "Aku mendengar Rasulullah SAW berkhutbah, beliau berkata:

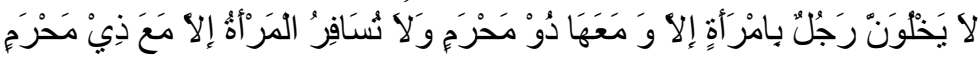

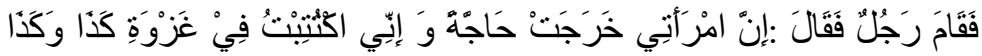

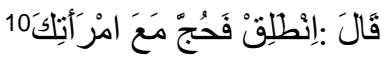

"Janganlah sekali-kali seorang lelaki menyendiri dengan seorang wanita kecuali wanita itu disertai mahramnya, dan tidak boleh seorang wanita bepergian kecuali bersama mahram, maka bangkitlah seorang lelaki lalu berkata: 'Sesungguhnya isteriku telah keluar untuk menjalankan ibadah haji, sementara aku telah diwajibkan untuk mengikuti sebuah peperangan', maka beliau bersabda: 'Pergilah dan kerjakan haji bersama isterimu."'

4. Rasulullah SAW bersabda:

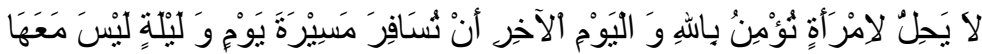

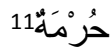

"Tidak halal bagi seorang wanita yang beriman kepada Allah dan hari akhir bepergian sejarak perjalanan sehari semalam tanpa disertai mahramnya"

5. Rasulullah SAW bersabda:

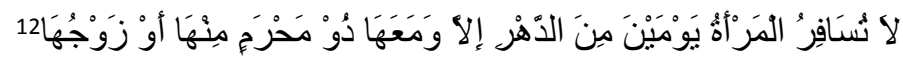

"Tidak boleh seorang wanita bepergian selama dua hari dari suatu masa, kecuali disertai oleh mahramnya atau suaminya."

10 Ibid, 978.

11 Abi Abdillah Muhammad Bin Isma'il Al-Bukhari, al-Jami' al-Sabih, juz 1, maktabah shamilah, hlm. 368

12 Muslim bin al-Hajjaj Abu al-Hasin al-Qushairi al-Naisaburi, Sabib Muslim, juz

2, maktabah shamilah, 975 
Beberapa hadis di atas menjelaskan bahwa seorang perempuan harus didampingi mahramnya ketika melakukan suatu perjalanan. Alasan paling rasional adalah agar mahramnya bisa menjaganya dan memberikan keamanan selama perjalanan berlangsung.

Lalu tentang siapakah mahram perempuan itu, sebenarnya di beberapa kitab fiqh tidak dijelaskan secara konkrit tentang mahram perempuan. Penjelasan yang biasanya dipaparkan adalah para mahram bagi laki-laki sebagaimana dijelaskan dalam al-Qur'an surat an-Nisa' ayat 23. Oleh karena itu, mahram bagi perempuan adalah kebalikan dari mahram bagi laki-laki, yaitu setiap orang yang diharamkan menikahinya dengan pengharaman yang bersifat selamanya, baik karena hubungan kekerabatan, persusuan atau karena hubungan pernikahan. Rinciannya sebagaimana berikut:

1. Mahram (bagi seorang wanita) karena hubungan kekerabatan ada tujuh:

a. Ayah, kakek dan seterusnya ke atas, baik dari pihak ayah maupun ibu.

b. Anak laki-lakinya, anak laki-laki puteranya, anak laki-laki puterinya dan seterusnya ke bawah.

c. Saudara laki-laki (seayah seibu), saudara laki-lakinya yang seayah dan saudara laki-lakinya yang seibu.

d. Anak laki-laki saudara laki-laki sekandung, anak laki-laki saudara laki-lakinya yang seayah dan anak laki-laki saudara laki-lakinya yang seibu.

e. Anak laki-laki saudara perempuan yang sekandung (seibu seayah), anak laki-laki saudara perempuannya yang seibu.

f. Pamannya (saudara laki-laki ayahnya) baik saudara sekandung atau saudara laki-laki ayah yang seayah atau saudara laki-laki ayah yang se-ibu.

g. Saudara laki-laki ibu, baik saudara se-kandung atau saudara laki-laki ibu yang seayah, atau saudara laki-laki ibu yang seibu. $^{13}$

2. Mahram karena hubungan persusuan

${ }^{13}$ Muhammad Nawawi, Taushih 'ala ibni qasim, (Surabaya: Mahkota, tt) hlm 201. 
Holilur Rohman: Reinterpretesi Konsep Mahram...

Mahram seorang wanita karena persusuan sama dengan mahramnya karena hubungan kekerabatan, berdasarkan sabda Nabi SAW:

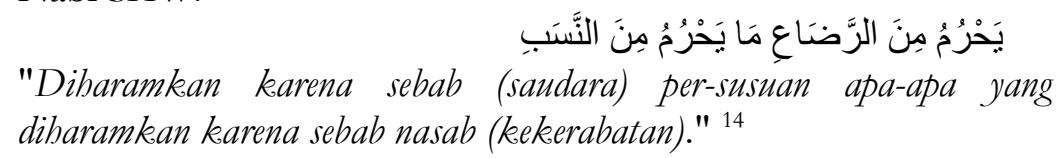

3. Mahram (bagi seorang wanita) karena pernikahan

Mahram bagi seorang wanita karena sebab pernikahan adalah:

a. Anak laki-laki suami dan putera-puterinya, putera-putera (anak laki-laki) dari anak perempuan suami dan seterusnya ke bawah, sama saja apakah mereka itu dari isteri yang sebelumnya (yang telah diceraikan) atau masih dalam ikatan perkawinan dengan atau dari isteri yang sesudahnya.

b. Ayah suaminya (mertua laki-lakinya), kakeknya dan seterusnya ke atas, sama saja apakah kakeknya itu dari pihak ayah suami atau ibu suaminya.

c. Suami anak perempuannya (menantu laki-lakinya) dan suami cucu perempuannya, baik cucunya itu dari anak laki-lakinya atau dari anak perempuannya, dan seterusnya ke bawah.

Ketiga orang yang disebutkan ini tetap menjadi mahramnya, hanya sekedar dengan melaksanakan akad nikah, sehingga kalaupun suaminya telah meninggalkannya karena mati atau karena talak (mentalaknya) atau karena fasakh (dipisahkan pernikahannya), maka mereka (ketiga golongan diatas) tetap sebagai mahram baginya (bagi wanita tersebut).

d. Suami ibu dan suami nenek dan seterusnya ke atas, namun demikian suami tersebut tidak bisa menjadi mahram bagi anak-anak perempuan isterinya, hingga dia telah mengumpuli isterinya tersebut. Jika dia telah mengumpulinya barulah dia menjadi mahram bagi puteri isterinya dan puteri cucunya, baik puteri itu dari suami sebelumnya atau suami sesudahnya,

14 Ibn Rushd, Bidayah al-Mujtahid, juz 2, (Surabaya: al-Hidayah, tt), 26. Dalam kitab ini Ibnu Rush menjelaskan panjang lebar tentang perbedaan pendapat ulama' terkait beberapa hal, diantaranya kadar keharaman dari persusuan, umur menyusui, dll. 
meskipun nantinya dia menceraikan isterinya itu. Jika dia hanya sekedar menjalankan akad nikah dengan seorang wanita, lalu dia menceraikannya sebelum mengumpulinya, maka dia tidak bisa menjadi mahram bagi anak Sperem-puan dan cucu perempuan mantan isteri-nya tersebut. ${ }^{15}$

\section{Perbedaan Ulama' Tentang Perjalanan Perempuan}

Dalam diskusi fiqh, seringkali orang hanya mengenal pandangan bahwa seorang perempuan yang akan bepergian dalam jangka waktu tertentu, terlepas untuk urusan apapun diwajibkan ditemani keluarga dekat yang disebut mabram, sebagaimana dijelaskan di beberapa hadis di atas. Keharusan mahram dampingan ini seringkali dihadirkan tanpa ada diskusi konteks sosial, alasan hukum, ragam teks-teks hadits yang menjadi dasar, maupun ragam pandangan para ulama fiqh itu sendiri.

Pengetahuan mengenai konteks suatu hukum dan ragam pandangan ulama sangat penting untuk memahami secara baik karakter hukum tersebut. Tanpa pengetahuan yang memadai dan dalam kealpaan perspektif yang ramah perempuan, misi perlindungan dalam konsep mahram pasti akan terlupakan ketika mengurai teks hadits dan pandangan hukum terkait penjelasan konsep ini.

Beberapa hadis pelarangan perempuan keluar tanpa mahram oleh beberapa ahli fiqh dijadikan dasar pengekangan dan domestifikasi perempuan. Penjelasan Imam as-San'ani (w. $1182 \mathrm{H} / 1850 \mathrm{M}$ ) terhadap teks hadits ini dalam kitab Subul alSalâm, bahwa larangan ini terkait fitnah tubuh perempuan, juga membenarkan konsep domestifikasi ini. Kitab ini juga mengapresiasi pandangan Imam Nawawi (w. 676H/1277M) yang melarang perempuan bepergian secara mutlak, tanpa pertimbangan waktu tiga hari sebagaimana dalam teks hadits di atas, jika tanpa ditemani mahram. Perempuan menjadi satu-satunya subyek hukum, yang terkena larangan bepergian tanpa mahram, hanya karena ia berjenis kelamin perempuan. ${ }^{16}$

15 Sayyid Sabiq, Fiqh al-Sunnah juz 1I, hlm. 249.

16 Dikutip dari , diakses tangal 2 Juni 2015. Rahima adalah salah satu LSM di Jakarta yang aktif mendiskusikan persoalan-persoalan terkait perempuan. 
Alasan bahwa perempuan adalah penyebab fitnah juga ditulis oleh Wahbah Zuhaili ketika membahas hukum perempuan yang keluar untuk melaksanakan sholat id. Menurut hanafiyah dan malikiyah, mereka sepakat bahwa tidak ada rukhsah untuk membolehkan perempuan keluar dalam rangka melakukan shalat jum'at, dua hari raya, dan shalat lainnya. Dasar pendapat mereka adalah ayat 33 surat al-Ahzab ${ }^{17}$, yaitu:

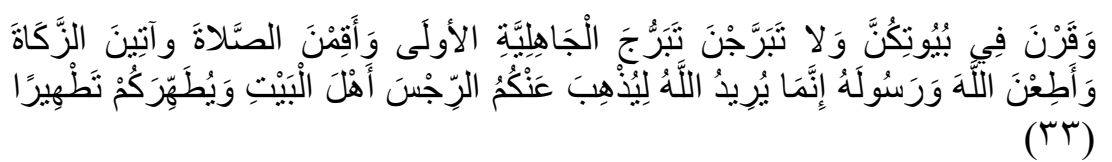

Artinya: Dan hendaklah kamu tetap di rumahmu dan janganlah kamu berbias dan bertingkah laku seperti orang-orang Jahiliyah yang dabulu dan dirikanlah shalat, tunaikanlah zakat dan taatilah Allah dan Rasul-Nya. Sesungsubnya Allab bermaksud bendake menghilangkan dosa dari kamu, Hai ablul bait dan membersibkan kamu sebersib-bersibnya.

Penjelasan konteks hadits kewajiban mahram dapat ditemukan dalam diskusi Ibn Hazm mengenai haji perempuan yang berangkat tanpa mahram. Menurutnya, perempuan diperbolehkan berangkat dan bepergian haji tanpa mahram sekalipun. Kewajiban mahram ada pada laki-laki untuk berangkat mendampingi perempuan. Jika tidak ada mahram, atau tidak ada yang bersedia menjadi mahram, maka perempuan sama sekali tidak dilarang untuk berangkat haji. Perempuan bisa dan boleh pergi sendirian berangkat haji tanpa mahram. Siapapun, termasuk suaminya, kata Ibn Hazm, tidak berhak melarang perempuan berangkat pergi haji.

Pandangan Ibn Hazm ini didasarkan pada beberapa teks hadits lain yang memberikan konteks hadits di atas, yaitu:

Rahima mempunyai media tulisan yang berjudul Swara Rahima. Penulis sendiri memiliki swara rahima edisi No. 33 Th. X Desember 2010 yang secara khusus membahas tentang memaknai kembali konsep mahram.

17 Wahbah Zuhaili, al-Fiqh wa Adillatubu, juz 2, (kairo: dar al-fikr, tt), 1389. 


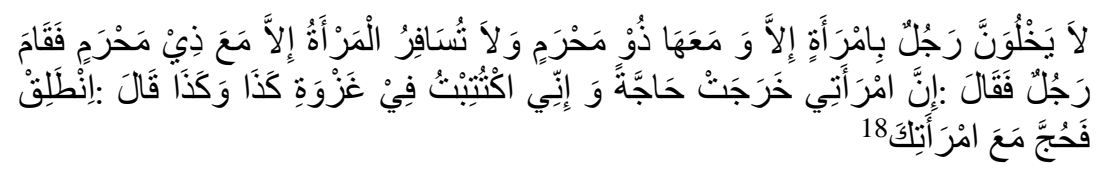

"Janganlah sekali-kali seorang lelaki menyendiri dengan seorang wanita kecuali wanita itu disertai mahramnya, dan tidak boleh seorang wanita bepergian kecuali bersama mabram, maka bangkitlah seorang lelaki lalu berkata: 'Sesunggubnya isteriku telah keluar untuk menjalankan ibadah haji, sementara aku telah diwajibkan untuk mengikuti sebuah peperangan', maka beliau bersabda: 'Pergilah dan kerjakan haji bersama isterimu."'

Tetapi pola pikir literal Ibn Hazm memaksanya melokalisasi persoalan ini hanya pada masalah haji saja. Dalam masalah lain, Ibn Hazm melarang perempuan pergi keluar rumah tanpa dampingan suami. Bahkan ia berpendapat, bagi perempuan diwajibkan untuk selalu taat pada suami, dan kewajiban ini jauh lebih tinggi daripada kewajiban-kewajiban lain selain masalah haji. Pola pikir ini tentu saja kembali mengaburkan misi perlindungan perempuan dalam konsep mahram, apalagi pembebasan dari pengekangan.

Mazhab Shafi'i, sebagai salah satu mazhab yang memperjuangkan analogi hukum Islam (qiyas), memiliki kekayaan diskusi persoalan mahram bagi perempuan yang bepergian. Ibn Hajar al-'Asqallani (w. 852H/1448M), ulama penda'wah utama mazhab ini, memaparkan berbagai pandangan ulama mazhab terkait alasan hukum dan moral etis terkait persoalan ini. Sayangnya, sedikit sekali orang yang membaca pemaparan ini, sehingga masih banyak yang terjebak pada kewajiban literal soal mahram ini.

Di samping berbagai pandangan yang tetap mewajibkan mahram, ketika memberikan komentar atas teks hadits mahram di atas dalam Kitab Fath al-Bari, Ibn Hajar juga meriwayatkan pandangan berbeda dari dua ulama besar Mazhab Syafi'i, baik teks maupun pandangan ulama terkait mahram dampingan tidaklah tunggal. Imam al-Karabîsî (w. 245H/859M), murid langsung Imam al-Shafi'i, menganggap tidak masalah bagi perempuan pergi

18 Muslim bin al-Hajjaj Abu al-Hasin al-Qushairi al-Naisaburi, Sahih Muslim, juz 2, maktabah shamilah, 978. 
berangkat haji atau umrah sendirian selama perjalanan itu aman. Dengan alasan keamanan ini, Imam al-Qaffal (w. 412H/1026M) dan Imam Abu al-Mahasin ar-Rayyani (w. 501H/1107M), berpendapat perempuan boleh bepergian untuk alasan apapun tidak hanya urusan haji.

\section{Teori Double Movement Fazlur rahman}

Teori double movement Fazlur Rahman tidak terlepas dari bacaannya terhadap hermeneutika barat atauapun klasik yang dipelajari. Baik hermeneutika barat atau klasik sama-sama memberik kontribusi besar pada metode penafsirannya, yang lebih dikenal dengan toeri double movement (gerakan ganda). Berikut kontribusi konkrit dari hermeneutika klasik dan barat dalam pemikiran Fazlur Rahman:

1. Kontribusi Pemikiran Hermeneutika Klasik

a. Konsep Tafsir dan Ta'wil

Fazlur Rahman lebih cenderung memilih tafsir ${ }^{19}$ dari pada ta'wil ${ }^{20}$ untuk memahami Al-Qur'an pada bangunan hermeneutikanya. Paradigma tafsir ini bermuara pada perumusan pandangan dunia Al-Qur'an dan ideal moral yang dikandung dalam teks Al-Qur'an. Sementara itu mediator yang digunakan Rahman untuk merumuskan pandangan dunia Al-Qur'an ini menggunakan perangkat bahasa (teks) dan konteks (asbab nuzul). ${ }^{21}$

b. Kontekstualisasi Al-Qur'an

Bangunan teoritik hermeneutika Fazlur Rahman dapat dipahami secara jelas dengan terlebih dahulu memahami konsep-konsep kunci (key concept) yang menjadi dasar konstruksi pemikiran hermeneutikanya, sebagaai

19 Tafsir adalah menjelaskan makna teks al-Qur`an dalam batas-batas kata dan ungkapannya, artinya penjelasan berdasarkan unsur kandungan dan komposisi linguistiknya semata

20 Ta'wil adalah pencarian makna tersembunyi dengan mengabaikan makna yang tampak (zabir) menuju makna yang lain

21 Ilyas Supena, Hermeneutika Al-Qur'an dalam Pandangan Fąlur Rabman, (Yogyakarta: Penerbit Ombak, 2014), 104. 
berikut: Pertama, Asbab an-Nuzul. ${ }^{22}$ Kedua, Qiyas. ${ }^{23}$ Ketiga, Illat Hukum ${ }^{24}$

2. Kontribusi Pemikiran Hermeneutika Barat

a. Pemikiran Hans-George Gadamer

Gadamer adalah salah seorang tokoh pemikir hermeneutika yang gagasannya banyak mempengaruhi pemikiran Rahman. Bagi Gadamer, salah satu tujuan terpenting dari hermeneutika adalah memperluas horison melalui ziarah imajinatif pada tradisi masa lampau dan berdialog dengan para jenius lewat karya tulisannya dalam setting sosial kehidupan mereka, sehingga akan muncul apa yang disebut the fusion of horizon ${ }^{25}$.

b. Kontribusi Pemikiran Emilio Betti

Menurut Betti, hermeneutik seharusnya dapat melahirkan penafsiran obyektif. Menurutnya, proses penafsiran adalah kebalikan dari proses penciptaan yang asal. Artinya, bentuk-bentuk yang dicoba dipahami dan ditafsirkan harus dibawa kembali kepada pikiran yang menciptakannya dimana bentuk-bentuk tersebut merupakan kandungan orisinal, tidak merupakan penafsiran sepotong-sepotong, tetapi sebagai satu kesatuan

22 Menurut Nasr Hamid Abu Zaid, Ilmu Asbab An-Nuzul bertujuan untuk menunjukkan hubungan dan dialektika antara teks dan realitas. Ilmu Asbab AnNuzul memandang turunnya teks sebagai respons atas realitas, baik dengan cara menguatkan atau menolak, dan menegaskan hubungan dialogis dan dialektik antara teks dan relita. Lihat: Nasr Hamid Abu Zaid, Tekstualitas Al-Quran; Kritik terhadap Ulumul Qur'an, Terj. Khoiron Nahdliyyin, (Yogyakarta: LkiS, 2003), hlm. 115.

${ }^{23}$ Ilyas Supena, Hermeneutika..., 81.

${ }^{24}$ Ibid, 88 .

${ }^{25}$ Konsep the fusion of horizon sebagaimana dikenalkan Gadamer, jika diletakkan dalam tradisi epistomologi tasawuf, barangkali terwakili dalam konsep "tahalli dan wabdat al-wujud". Ataupun yang lebih moderat, pada konsep kebenaran eksperiensial, bukan kebenaran eksperimental. Di sini sufi tidak berani mengakui dirinya yang mengetahui hakikat kebenaran, melainkan pengetahuan Tuhan yang telah masuk pada dirinyalah yang memungkinkan seorang Sufi mengenal kebenaran. Jika konsep fusi dalam hermeneutika arahnya horisontal, maka dalam tasawuf bersifat vertikal. Lihat: Komaruddin Hidayat, Menafsirkan Kehendak Tuhan, (Jakarta: Teraju, 2004), 104. 
yang koheren, lalu dihidupkan kembali dalam pikiran subyek yang melakukan penafsiran atasnya. ${ }^{26}$ Bagi Betti, makna dan maksud dari sebuah teks hanya diketahui oleh sang penulis itu sendiri. Selanjutnya, melalui pemahaman terhadap kesatuan teks dan penulisnya, makna dapat dihidupkan kembali dalam pikiran subjek penafsir. ${ }^{27}$ Dengan demikian, tugas penafsir menurut Betti adalah mengenali dan merekonstruksi ide-ide, pesan-pesan dan intensi-intensi penulis yang termanifestasikan di dalam objek tersebut. ${ }^{28}$

Diskursus hermeneutika di atas menjadi fundamen penting bagi pemikiran hermeneutika Rahman sehingga mengantarkannya pada metode pemikiran yang khas dan berbeda dari pemikir muslim lainnya. Menurut Fazlur Rahman, yang dikutip oleh Ghufron, ijtihad adalah upaya memahami makna suatu teks atau preseden di masa lampau yang mengandung suatu aturan, dan mengubah suatu aturan tersebut dengan cara memperluas atau membatasi ataupun memodifikasinya dengan cara-cara lain sedemikian rupa sehingga situasi baru dapat dicakup ke dalamnya dengan suatu solusi baru. ${ }^{29}$

Dari definisi inilah lalu Fazlur Rahman merangkai kerja ijtihadnya menjadi 3 langkah sebagai upaya pembaharuan hukum Islam, yaitu:

1. Memahami teks dalam keutuhan konteks di masa lampau

2. Memahami situasi baru yang terjadi sekarang

3. Mengubah aturan-aturan hukum yang terkandung dalam teks sebagai upaya pembaharuan hukum Islam ${ }^{30}$

Kerja ijtihad yang diusung Fazlur Rahman di atas mengantarkannya pada suatu teori hukum Islam yang dikenal dengan double movement. ${ }^{31}$ (gerakan ganda).

${ }^{26}$ Fazlur Rahman, Islam and Modernity Transformation of an Intellectual Tradition, (Chicago: Chicago University Press, 1982), 8.

${ }^{27}$ Ibid, 11.

28 Ilyas Supena, Hermeneutika Al-Qur'an dalam Pandangan Fazlur Rahman, (Yogyakarta: Penerbit Ombak, 2014), 118.

${ }^{29}$ Ghufran A. Mas'adi, Pemikiran Fąlur Rahman tentang Metodologi Pembaharuan Hukum Islam, (Jakarta: Raja Grafindo Persada, 1997), 148.

${ }^{30} \mathrm{Ibid}, 149$. 


\section{Gerakan Pertama}

Gerakan pertama ini terdiri dari dua langkah, yaitu:

1. Memahami makna teks dengan cara mengkaji secara spesifik sosio historis sebuah teks serta mengkaji situasi makro keseluruhan kehidupan masyarakat arab pada saat Islam datang khususnya di mekkah dan sekitarnya.

2. Mengeneralisasikan respon-respon spesifik dari makna teks (pada langkah pertama) dan mengungkapkannya sebagai ungkapan-ungkapan yang memiliki tujuan moral sosial umum. Ungkapan ini bisa disaring dari teks-teks spesifik dengan melihat rationes legis (illat hukum). ${ }^{32}$

Illat hukum versi Fazlur Rahman dikembangkan menjadi sebuah upaya menetapkan prinsip-prinsip umum yang terkandung di dalam hukum dan untuk menetapkan tujuan moral sosial yang terkandung dalam legislasi al-Qur'an dan sunnah. Dalam literatur usul fiqh disebut dengan maqasid al-shari'ah. ${ }^{33}$

\section{Gerakan Kedua}

Gerakan kedua adalah upaya perumusan prinsip-prinsip umum, nila-nilai, dan tujuan-tujuan al-Qur'an atau sunnah yang telah disistematisasikan melalui gerakan pertama, terhadap situasi dan atau kasus aktual sekarang ini. ${ }^{34}$ Teori Rahman di atas dapat diskemakan sebagai berikut:

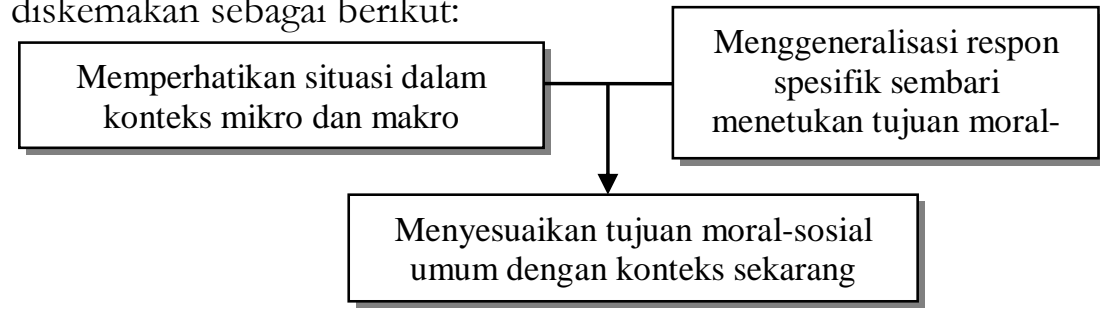

\footnotetext{
31 Wael B. Hallaq, Sejarah Teori Hukum Islam: Pengantar untuk. Ushul Fiqh Madzhab Sunni, (Jakarta: Rajawali Press, 2000), hlm. 362. Fazlur Rahman, Islam dan Modernitas..., 6-10.

32 Ghufran A. Mas'adi, Pemikiran Fąlur Rahman, 152.

${ }^{3}$ Ibid, 157.

34 Ibid, 161.
} 


\section{Reinterpretasi Hadis Tentang Mahram dan Dampaknya Terhadap Status Hukum Perjalanan Perempuan dalam Pembacaan Hermeneutika Fazlur Rahman}

Pada dasarnya konsep mahram merupakan konsep perlindungan bagi mereka yang lemah, dalam konteks hadis nabi di atas adalah perempuan. Akan tetapi konsep mahram ini juga bisa berubah menjadi ajaran-ajaran pembatasan dan pelarangan hal-hal yang remeh. Penyelewengan pemahaman ini bisa dijelaskan dari persoalan kesadaran yang timpang dalam melihat perempuan dan mereka yang lemah. Oleh karena itu perlu ditegaskan kembali misi perlindungan dalam konsep mabram, sebagaimana pada awalnya ditegaskan Islam.

Memang secara spesifik Fazlur Rahman tidak membahas tentang status hukum perempuan bekerja di luar rumah atau nasib TKW yang terjadi di berbagai Negara, khususnya di Indonesia. Oleh karenanya kami tidak bisa memaparkan lebih jauh bagaimana pendapat Fazlur Rahman tentang TKW atau perjalanan perempuan secara umum.

Di sini penulis hanya menggunakan teori Double Movement Fazlur Rahman sebagai pisau analisa untuk membahas perjalanan perempuan, khusunya yang terkait dengan para tenaga kerja wanita yang bekerja di luar negeri. Dari teori inilah penulis ingin menganalisa dan berusaha mereaktualisasi makna hadis yang melarang perempuan melakukan perjalanan tanpa didampingi mahramnya.

Menurut kami, sesuai dengan teori Fazlur RahmanGerakan pertama yang akan dilakukan adalah berusaha memahami latar belakang historis secara spesifik ataupun secara makro kehidupan masyrakat arab, khususnya di mekkah dan madinah. Lalu dilanjutkan proses generalisasi makna teks serta menyatakannya dalam ungkapan-ungkapan yang bertujuan moralsosial umum.

Setelah melihat beberapa refrensi yang kami dapat, larangan yang terdapat pada hadis diberlakukan dalam situasi di mana orang terbiasa bepergian dengan menunggang kuda, unta, ataupun khimar. Mereka melintasi gurun-gurun pasir yang membentang, dan nyaris tak ada penduduk atau bangunan apapun. 
Bagi perempuan yang bepergian sendirian tentu sangat berbahaya. Meskipun dirinya tidak ditimpa marabahaya, akan tetapi bahaya itu selalu mengancam kehormatannya. ${ }^{35}$

Selain alasan geografis, bahwa kehidupan nomaden dan kecenderungan patriarkhis-misoginis pada saat itu masih belum banyak berubah, meski Nabi sudah memeperingatkan berulang kali bahwa manusia pada dasarnya adalah sama sehingga perendahan atas tubuh perempuan dan pelecehan seksual atasnya tidak boleh lagi terjadi. ${ }^{36}$

Dilihat dari segi konteks sistem sosial-ekonomi, bangsa arab pada abad $7 \mathrm{M}$ dalam skala umum dan global adalah agraris (pertanian), meski tidak berarti tanpa aktifitas ekonomi perdagangan. Oleh karena itu aktivitas kehidupan sehari-hari masyarakat tidaklah sesibuk dan semaju konteks masyarakat pada abad sekarang dengan situasi sosial-ekonomi perdagangan, industri, dan tekhnologi komunikasi atau transportasi. ${ }^{37}$

Dari berbagai latar belakang diatas (geografis, sosial, dan ekonomi) kami menyimpulkan bahwa alasan di balik larangan (perempuan tidak boleh bepergian seorang diri) adalah kekhawatiran terhadap keamanan perempuan saat bepergiaan seorang diri, tanpa ditemani suami atau seorang mahram. Dalam kondisi seperti ini, hukum kewajiban mahram bagi perempuan bepergian bersifat kontekstual, karena rasio-legis dari dari kewajiban ini adalah untuk memberikan perlindungan dan keamanan kepada perempuan.

Perintah penyertaan mahram dalam perjalanan perempuan pada dasarnya adalah salah satu mekanisme atau cara melindungi perempuan dari kemungkinan-kemungkinan yang tidak dikehendaki. Dengan kata lain, mekanisme atau cara melindungi perempuan dalam konteks sosial zaman nabi adalah melalaui penjagaan individu atau personal laki-laki keluarga dekatnya.

Lalu bagaimana dengan gerakan kedua dalam aplikasi teori double movement Fazlur Rahman, maka langkah selanjutnya

35 Tim redaksi, Swara Rahima, No. 33 Th. X Desember 2010, hlm. 23.

${ }^{36}$ Ibid.

${ }^{37}$ Ibid. 
adalah melihat situasi dan kondisi masa sekarang, baik dari segi geografi, sosial, mapun ekonomi.

Dewasa ini peradaban masyarakat modern telah jauh berubah dan berbeda dengan situasi, zaman, dan peradaban ketika hadis mahram muncul di dunia arab pada awal-awal Islam. Komunikasi dunia hari ini berada dalam zaman tekhnologi komunikasi dan transportasi yang teramat canggih. Kampungkampung pun telah banyak yang menjadi kota dengan segala infrastrukturnya yang jauh lebih lengkap dari pada sebelumnya. Tingkat mobilitas manusia begitu cepat. Ruang-ruang kerja sangat terbuka, bahkan relasi dan komunikasi antar masyarakat dunia seakan tidak lagi tersekat oleh ruang-ruang geografis.

Oleh karena itu, dalam konteks sosial, ekonomi, kebudayaan yang jauh telah berubah ini, maka konsep mahram yang pada awalnya dipahami dan diformat sebagai person atau individu, seharusnya mengalami perubahan konsep dan format dengan tetap mempertahankan esensinya berupa perlindungan dan penjamin keamanan bagi seorang perempuan.

Di sinilah menurut kami urgensitas mengetahui ilmu-ilmu umum untuk membantu mempertajam analisa us $\}$ ul figh dan maqasid al-syariah ketika dihadapkan pada realitas kekinian . Us\} ul fiqh dan maqasid al-syariah akan sangat membutuhkan keilmuan yang terkait dengan pengetahuan sosial, ekonomi, geografi, dan lainnya sebagai alat bantu mengetahui objek kajian yang sedang dibahas dan diteliti. Bagaimana akan mengetahui sistem ekonomisosial suatu masyarakat jika tidak pernah tahu sosiologi atau ekonomi.

Selanjutnya, ketika kondisi telah berubah, maka "kewajiban ditemani mahram" bisa diganti dengan media lain yang secara faktual bisa memenuhi tujuan perlindungan dan keamanan yang diperlukan. Sebagaimana pada zaman kita sekarang, untuk bepergian jauh, orang bisa menggunakan pesawat, maupun kereta api, yang dapat menampung penumpang dengan jumlah banyak dengan jaminan keamanan tertentu. Karenanya, seorang perempuan tidak merasa khawatir lagi untuk bepergian seorang diri. ${ }^{38}$

${ }^{38}$ Ibid, 24. 
لا ينكر تغير الأحكام بتغير Dalam kaidah fiqh disebutkan لألأزمان (tidak bisa diingkari bahwa perubahan hukum disebabkan karena perubahan zaman). ${ }^{39}$ Oleh karena itu kami menyimpulkan bahwa jika perlindungan atas keamanan perempuan adalah esensi mahram, maka penciptaan situasi atau ruang serta perumusan mekanisme yang kondusif bagi perlindungan terhadap perempuan haruslah menjadi perhatian utama.

Sedangkan mekanisme modern bagi konsep perlindungan masyarakat baik secara individu maupun kolektif antara lain melalui aturan-aturan hukum, perundang-undangan, dan kebijakankebijakan publik, khususnya bagi para Tenga Kerja Wanita (TKW) yang mengadu nasibnya di luar negeri untuk bekerja. ${ }^{40}$

\section{Perspektif Migrant Care ${ }^{41}$}

Sekedar menambahkan dan menguatkan analisa penulis di atas, kami memberikan pendapat yang diberikan oleh Anis Hidayat, Direktur Eksekutif Migrat Care. Anis Hidayat menyatakan bahwa konsep mahram bagi TKI dan TKW pada khususnya adalah perlindungan Negara. ${ }^{42}$ Dengan demikian, larangan perempuan bepergian tanpa mahram adalah kondisional dan untuk kepentingan perlindungan perempuan. Kepentingan ini pada saat sekarang bisa diwujudkan melalui kebijakan-kebijakan yang memberikan perlindungan setiap orang yang ada dalam perjalanan, dengan menambahkan pengawasan, atau dengan mempermudah teknik perjalanan.

Lebih lanjut Anis Hidayat menjelaskan bahwa yang butuh perlindungan sebenarnya bukan hanya pekerja migrant perempuan, tetapi juga pekerja laki-laki. Migrant Care mencatat ada beberapa kasus yang mana pasangan suami dan istri pergi ke arab untuk menjadi TKI, kaena memang ada kebutuhan majikan untuk tukang kebun dan PRT. Tapi hal ini juga tidak sama sekali menjamin tidak adanya pelanggaran. Fakta yang ada bahwa para TKW tidak

39 'Amad 'Ali Jum'ah, al-Qawaid al-Fiqhiyyah al-Muyassarah, (Ardan: Dar al-Nafais, 2006), 68.

40 Tim redaksi, Swara Rabima, No. 33 Th. X Desember 2010, 25.

${ }^{41}$ Sebagai catatan, Migrant Care adalah sebuah lembaga yang peduli terhadap hak-hak para pekerja migrant Indonesia.

42 Tim Redaksi, Swara Rabima, No. 33 Th. X Desember 2010, 16. 
mengenal jam kerja (over-time), tidak bisa keluar rumah, tidak punya hari libur, gaji yang rendah, dan sebagainya. Jadi prinsip kerja paksa (force labour) dan perbudakan (slavery) itu tetap terjadi di arab dengan wajah yang berbeda walaupun para TKW didampingi suaminya. ${ }^{43}$

Faktor yang menyebabkan hal tersebut adalah bahwa daya tawar TKI sangat rendah di hadapan negara-negara tujuan. Ditambah lagi bahwa ranah buruh migrant Indonesia adalah ranah domestik atau pekerja rumah tangga. Sebagaimana dicatat oleh Migrant Care, pekerja rumah tangga bagi para TKI menjadi sektor yang mayoritas, hamper $83 \%$ buruh migrant Indonesia adalah TKI. Dan yang membuat mereka rentan adalah karena sampai saat ini, di level internasional pun belum ada prinsip-prinsip yang menjadi hak-hak PRT. ${ }^{44}$

Bagi Anis Hidayat, yang dibutuhkan para TKW bukanlah seorang seorang pendamping, tetapi lebih pada proteksi hukum. Langkah konkrit yang dilakukan Migrant Care adalah terus mengawal dan mendorong kebijakan migrasi yang memiliki perspektif HAM dan Gender. Selama ini Migrant Care berkonsentrasi untuk mendorong DPR agar melakukan revisi UU no. 39 tahun 2004 tentang penempatan dan perlindungan TKI. ${ }^{45}$

Dalam kaidah fiqh disebutkan: بلتصرف على الرعية منوط (perbuatan dan kebijakan pemimpin haruslah bersandarkan pada kamaslahatan rakyat secara umum). ${ }^{46}$ Oleh karena itu seharusnya pemerintah mempunyai peran aktif dalam upaya proteksi hukum untuk melindungi para buruh migrant. Hal penting yang harus diperhatikan adalah revisi UU no. 39 nanti harus memasukkan gender sebagai perspektif, karena mayoritas TKI adalah perempuan. UU TKI yang ada sekarang tidak memiliki perspektif gender (gender blank). Kalau pemerintah sejak awal memasukkan aspek gender di dalam setiap regulasi, maka bisa diketahui, karenaya seperti apa, dan bagaimana cara mengatasinya. ${ }^{47}$

${ }^{43}$ Ibid, 17.

${ }^{44}$ Ibid, 17.

45 Ibid, 19.

46 'Azat Ubaid al-Da'as, al-Qawaid al-Fiqhiyah, (Beirut: dar al-Tirmizi, 1989), 107.

${ }^{47}$ Ibid, 20. 
Anis Hidayat lebih lanjut mengusulkan, Pemerintah Indonesia seharusnya menggunakan konvensi CEDAW sebagai refrensi karena sudah diratifikasi selama 25 tahun. Hak untuk bekerja (rights to work) adalah satu hal yang dijamin di dalam CEDAW. Apalagi komite CEDAW memiliki General Recomendation 26 tentang buruh migrant perempuan. Ini harus menajdi refrensi bagi regulator yang menggodok UU TKI, dan pemerintah eksekutifpun harus proaktif. ${ }^{48}$

Dari beberapa pnejalsan Anis Hidayat dia atas kami bertambah yakin bahwa konsep mahram yang sebenarnya adalah perlindungan terhadap perempuan ketika melakukan perjalanan, khususnya perjalanan untuk bekerja di luar negeri. Pemerintah harulah menjadi garda terdepan yang menjamin keamanan para TKW dengan berbagai katuran-aturan dan kebijakannya.

Akan tetapi, pada konteks jaminan perlindungan dan keamanan itu tidak diperoleh dari negara tujuan, sebagaimana kasus-kasus yang terjadi di Saudi Arabia saat ini, negara berhak melakukan moratorium (penghentian sementara) untuk memastikan kebijakan perlindungan bisa diberikan. Dalam us\}ul fiqh ada teori yang disebut saz al-zariah, yaitu memotong jalan kerusakan (mafsada) sebagai cara untuk menghindari kerusakan tersebut. Meski suatu perbuatan bebas dari unsur kerusakan, namun jika perbuatan itu merupakan jalan atau sarana terjadi kerusakan, maka kita harus mencegah perbuatan tersebut. ${ }^{49}$ Jika pengiriman TKI ke luar negeri justru membahayakan mereka, maka pemerintah seharusnya melakukan moratorium. Hal ini dilakukan setelah mengadakan kajian-kajian mendalam serta mengumpulkan data akurat tentang fakta yang terjadi di lapangan terkait kasus-kasus yang menimpa para TKI di luar negeri.

\section{Kesimpulan}

Dari berbagai uraian penjelasan diatas, ada beberap kesimpulan yang perlu penulis sebutkan. Yaitu:

48 Ibid.

49 'Abdul Karim Zaidan, al-W ajiz fi Usul al-Figh, ('Amman: Maktabah al-Bathair, 1994), 245. 
1. Ada beberapa hadis yang menjelaskan tentang perjalanan perempuan, diantaranya

a. Dari 'Abdullah bin 'Umar Radhiallaahu anhu, bahwasanya Nabi Shalallaahu alaihi wasalam bersabda:

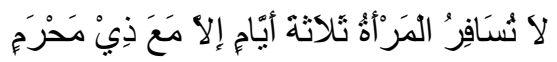

b. Rasulullah Shalallaahu alaihi wasalam bersabda:

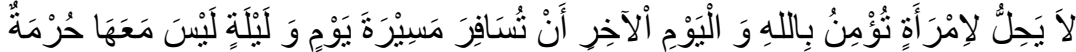

2. Imam Nawawi berpendapat bahwa perempuan dilarang bepergian secara mutlak, tanpa pertimbangan waktu tiga hari sebagaimana dalam teks hadits di atas, jika tanpa ditemani mahram. Alasannya adalah bahwa perempuan adalah penyebab fitnah.

Menurutnya ibnu hazm, perempuan diperbolehkan berangkat dan bepergian haji tanpa mahram sekalipun. Akan tetapi dalam masalah lain, Ibn Hazm melarang perempuan pergi keluar rumah tanpa dampingan suami.

Imam al-Karabîsî (w. 245H/859M), murid langsung Imam asyShafi'i, menganggap tidak masalah bagi perempuan pergi berangkat haji atau umrah sendirian selama perjalanan itu aman. Dengan alasan keamanan ini, Imam al-Qaffâl (w. 412H/1026M) dan Imam Abu al-Mahâsin ar-Rayyâni (w. $501 \mathrm{H} / 1107 \mathrm{M})$, berpendapat perempuan boleh bepergian untuk alasan apapun tidak hanya urusan haji.

3. Alasan di balik larangan (perempuan tidak boleh bepergian seorang diri) adalah kekhawatiran terhadap keamanan perempuan saat bepergiaan seorang diri, tanpa ditemani suami atau seorang mahram. Dalam pernyataan ini seperti ini, hukum kewajiban mahram bagi perempuan bepergian bersifat kontekstual, karena rasio-legis dari dari kewajiban ini adalah untuk memberikan perlindungan dan keamanan kepada perempuan. Jadi, perintah penyertaan mahram dalam perjalanan perempuan pada dasarnya adalah salah satu mekanisme atau cara melindungi perempuan dari kemungkinan-kemungkinan yang tidak dikehendaki.

Sedangkan mekanisme modern bagi konsep perlindungan masyarakat baik secara individu maupun kolektif antara lain melalui aturan-aturan hukum, perundang-undangan, dan 
kebijakan-kebijakan publik, khususnya bagi para Tenga Kerja Wanita (TKW) yang mengadu nasibnya di luar negeri untuk bekerja.

\section{Daftar Pustaka}

Abi Abdillah Muhammad Bin Isma'il Al-Bukhari. al-Jami' al-Sabih, juz 4, Maktabah Shamilah.

'Azat Ubaid Al-Da'as. Al-Qawaid al-Fiqhiyah. Beirut: Dar al-Tirmizi, 1989.

Muslim bin al-Hajjaj Abu al-Hasin al-Qushairi al-Naisaburi. Sabih Muslim, juz 2, Maktabah Shamilah.

Mustafa al-Siba'i. al-Mar'ah bain al-Fiqh wa al-Qanun. Kairo:Dar alSalam, 1998.

Damanhuri, Belajar Teori Hermeneutika bersama Betti, dalam Hermeneutika Transendental, ed. Nafisul Atho' \& Arif Fahrudin, Yogyakarta: IRCiSoD, 2003.

Komaruddin Hidayat. Menafsirkan Kehendak Tuban. Jakarta: Teraju, 2004

Ibn Rushd, Bidayah al-Mujtabid, juz 2. Surabaya: al-Hidayah, tt.

'Amad 'Ali Jum'ah. Al-Qawaid al-Fiqhiyyah al-Muyassarah. Ardan:

Dar al-Nafais, 2006.

Ghufran Mas'adi. Pemikiran Fąlur Rahman tentang Metodologi

Pembaharuan Hukum Islam. Jakarta: Raja Grafindo Persada, 1997.

Muhammad Nawawi. 'Uqud al-Lujain. Surabaya, Dar al-'Abidin, tt.

----.-. Taushib\} 'Ala Ibni Qasim. Surabaya: Mahkota, tt.

Fazlur Rahman. Islam dan Modernitas Tantangan Transformasi Intelektual, Cet. III, Ter. Ahsin Mohammad, Bandung: Pustaka, 2005.

------. Tema Pokok, Al-Qur'an, Cet. II, Bandung Pustaka, 1996.

Sayyid Sabiq. Fiqh al-Sunnah juz 1I. Kairo: Dar al-Fath1995.

Sibawaihi, Hermeneutika Al-Qur'an Fąlur Rabman, Yogyakarta: Jalasutra, 2007.

Ilyas Supena. Hermeneutika Al-Qur'an dalam Pandangan Fąlur Rabman. Yogyakarta: Penerbit Ombak, 2014

Nasaruddin Umar. Argumen Kesetaraan Gender Perspektif al-Qur'an. Jakarta: Paramadina, 2001. 
Holilur Rohman: Reinterpretesi Konsep Mahram...

Ahsin Wijaya. Teori Interpretasi Al-Qur'an Ibnu Rusyd Kritik Ideologis Hermeneutis, Yogyakarta: LKiS, 2009.

Nasr Hamid Abu Zaid. Tekstualitas Al-Quran; Kritik terhadap Ulumul Qur'an, Terj. Khoiron Nahdliyyin. Yogyakarta: LkiS, 2003

'Abdul Karim Zaidan. Al-Wajiz fi Usul al-Fiqh. 'Amman: Maktabah al-Bathair, 1994.

Wahbah Zuhaili. Al-Fiqh wa Adillatubu, juz 2. Kairo: Dar al-Fikr, tt.

www.rahima.or.id.

Tim Redaksi. Swara Rabima. No. 33 Th. X Desember 2010.

Tim Redaksi Nuansa Aulia. Kompilasi Hukum Islam. Bandung: Nuansa Aulia, 2008. 